\title{
POST-MODERN REPRESENTATION IN CEROS AND BATAZOR NOVELS WRITTEN BY TERE LIYE: JEANS FRANCOIS LYOTARD POST-MODERNISM
}

\author{
Muna Alfadlilah \\ Universitas Trunojoyo Madura \\ e-mail:Una_fadilah@yahoo.com
}

\begin{abstract}
Literature work is a notion which results a masterpiece with certain characteristics and it has aesthetics value. Understanding and enjoying literature work requires literature theoretical understanding. Literature theory explains to readers which will lead to a certain understanding or theory in a phenomenon consisted in it. This research aims to describe post-modern cultural aspects based on Jhon Francois Lyotard's theory in a novel written by Tere Liye, Ceros and Batazor edition. Tere Liye's novel has data elaborating post-modernism aspects, such as electism, parody, pastiche, irony, and camp. The data source of this research is a novel written by Tere Liye, Ceros and Batazor edition. The data collection was done by reading and noting methods. This research was done by identifying, clarifying, analyzing, elaborating, and drawing in order to create conclusion within postmodern aspects in which represented social life as described in novel written by Tere Liye, Ceros and Batazor edition. The findings of Tere Liye's novel describes fantasy and adventure words mixed in human lives and activities. They describe postmodern elements through several aspects. The research in Tere Liye's novel, one of them is electism in which its behavior combines local and foreign cultures both from language or foreign good aspects. The parody element is uttered as criticism to describe or quip certain behaviors or activities done by society. Meanwhile, pastiche, in the novel is an event lasting as principles stated in the novel. Irony is a description of an unexpected occurred event or destiny. Camp in the novel is an emphasis on the characters' behaviors which result to interpretation.
\end{abstract}

Keywords: electism, parody, pastiche, postmodern aspect, irony. 


\section{BACKGROUND}

Literature work is a medium to express an excellent masterpiece which has aesthetic values. One of them is imagination element. The existence of literature work in human life could enrich knowledge and critical analysis. Besides that, in the literature work, it provides amusement and benefit as presented by the author to its readers. Human nature, as a creature, functions to express and to put interest in real life as well as in imaginary work which are dreamed as an actual world. Thus, literature world, as a world of authors, is full of life realities since authors in creating literature works are based on two different realms (Aminuddin, 1991:12). Besides that, literature work has relationship with textual elements both inside and outside of the texts which could represent ages, eras, or even broader problems occurring in live which would have made the stories felt as realities.

Novel is a product of literature work which is preferred by society to read. There are two types of novel, fiction and non-fiction. The novel types have their own characteristics based on the authors. At present time, there are many of them becoming research object or analysis. As the time goes on, literature develops quickly. Not only that one, literature work also influences authors' ideas whom will express their ideas into literature works. Literature will always exist as the age goes on. It will never be separated from modernism which is assumed to have been outdated and is replaced by post-modern paradigm (Hatija, 2013:4). Post-modern is a term emerging from criticism toward modernism on the previous era. Therefore, post-modern appears with its new ideas to replace those narrow perspectives as presented by modernity. Besides that, post-modern does not only focus on science aspect but also science about old human and old human lives. Even, it also focuses on art work (Rachmawati, 2017:174).

Several arguments state that the beginning of post-modern term coming from Lyotard. Jean Francois Lyotard is a France philosopher in his book "The Post Modern Condition: A Report on Knowledge" which denied the basic notions of modern philosophy since Renains' era until present time which is legalized by ontological unit principles. Post-modern movement frequently emerges as criticism and modernized human failures in creating better social, conducive, and fair situations. Modern life is judged to not capable of preventing war inflict, social dynamic, and revolution which cause anarchy and total relativism (Rachmawati, 2017:16). According to Lyotard, post-modern is a termination of total connectivity (discontinuity) with modern culture and it is not only a correction upon several thoughts. Post-modern is defined as distrust on the truth of objective - universal science claim. This denial toward those narrations means it is the ending of a universal explanation about behaviors in instrumental rationality (Lyotard, 1982:11).

Tere Liye is a famous contemporary literature known from his novel works. The novels are preferred by various segments of society. Ceros and Batazor novel edition, written by Tere Liye, is a science fiction novel.The novel is in fifth order of Tere Liye's previous novels; they are Bumi, Bulan, Matahari, and Bintang. The novel tells scientific fiction events which tell adventure realms of the novel characters.

\section{RESEARCH METHOD}

The research methodology applied in this research is a descriptive - qualitative method since the data was taken from post-modern aspects in the novel. The researcher identified the aspects which showed post-modern aspect evidence in Tere Liye's novel. 
The research object in this Tere Liye's novel, Ceros and Batazor edition, is the fifth scientific fiction novel from Bumi, Bulan, Matahari, and Bintang. The novel was published in 2018 by Gramedia Pustaka Utama, Ltd. In analyzing the novel of Tere Liye's, Ceros and Batazor edition, was done through several stages. First, close reading was done several times. Second, identifying the aspects of the novel was done. Finally, it was continued by writing research conclusion.

\section{Findings and Discussion}

Tere Liye's novel work provides descriptions to the readers of how the author could bring the readers scientific fiction world with interesting story plot and content which has characteristics on each story plot. In the analysis below, it would identify aspects which showed the evidence of lives at post-modern which could change society to be more advance with technology and broader science. Here are the aspects contained in Jhon Francois Lyotard.

\section{Electism}

Electism is a zero degree of common contemporary culture and it could be observed from the behavior of combining our own national cultures, activities on where we are, and adopting behaviors of the users on different countries (Faisal, 2013). As described in Tere Liye's novel, Ceros and Batazor edition, it could be observed from the characters' activities.

"ya kami menyebutnya printer 3D. Masukkan rancangan mangkuk dikomputer, misalnya, lantas tekan enter, printer 3D akan mencetaknya sama persis seperti rancangan itu dari material yang ada. Bukan hanya mangkuk, mereka juga sudah bisa mencetak benda-benda rumit lain nya secara langsung dari file digital" (Liye, 2018: 93).

The excerpt describes character activity which combines daily lives with the existing lives which have changed quickly and practically. As described in the excerpt, that a bowl is an instrument to eat. However, by the advance of bowl technology which is made from materials, such as plastics or glasses, bowl now has changed to be more advance. It is just like by using computer typed technology, designing by using it, and creating any type of design. Besides computer, there is also 3D printer applied to print different types of matters with exactly forms in the computer. The things would facilitate the users practically and quickly. The evidence of the sentence describes that life situation does not last in fundamental structure moreover on post-modern era which all things could be done easily, included in technology.

Besides the uses of printed goods from the technology, there are other types of contemporary cultures, such as sports or techniques from overseas. They are as written in this text below.

“Apakah itu seni bela diri yang dikuasainya?" bisik Seli

Ali mengangguk.

"Itu seperti induk dari puluhan jenis bela diri ternama di klan Bumi. Mulai dari Kungfu, shorinji kempo, kalarippayatu, taekwondo, ninjutsu, wing chun dan yang lain nya. Seluruh konsep, ciri khas, dan kelebihan dari berbagai jenis bela diri itu menjadi satu dalam seni bela diri Batazor" (Liye, 2018: 267). 
In the excerpt, it explains that martial art types of sports are combined by other types of sports from overseas, such as Kung Fu from China, Shorinji Kempo from Japan, Kalarippayatu from India, Taekwondo from Korea, Ninjutsu from Japan, and Wing Chun from China. The martial arts have different concepts and characteristics of each country. The activities done by the characters in the novel are proving that the martial arts could be learned from various countries. It proves that post-modern concept is born by the distribution of martial arts from country to country.

" kalian kenakan ini." Ali mengambil dua gadget kecil dari dalam ranselnya, lalu menyerahkan kapadaku dan Seli. Benda ini alat komunikasi, seperti ponsel, tapi lebih canggih. Pasang ditelinga kalian dan kalian bisa mendengar percakapan jarak jauh juga bicara denganku" (Liye, 2018: 173).

In the dialog, there is a term, gadget. It indicates that this sophisticated tool made from overseas. This communication tool uses applied in the previous ages were face to face or by using other tools which were not as sophisticated as in the dialog. Gadget is a sophisticated communication tool in this age. There are many societies whom have been familiar with gadget because of the development and inventions done by Western People.

"Ini teknik yang lebih klasik, Seli, Raib. Ini bukan Shaolin, tai chi, atau seperti dalam film-film laga. Ini seperti itu, tapi dalam kesatuan yang rumit dan sepuluh kali hebat. Klan Bulan memiliki peradaban lebih tua" (Liye, 2018: 229).

In the excerpt, it explains that post-modern and culture are popular to influence life. Arguments about post-modern emphasize on style, effect, and specific images which will deal with social narration and criticism. One of them is Shaolin or Shaolin temple located in Song Mountain, near Zengzhou, in Henan province. However, in the excerpt, the referred Shaolin is a box office movie from Hong Kong in 2011. Meanwhile, Tai Chi master is a movie of Hong Kong in 1993. Those movies showed actions which were done by sophisticated techniques and merciless story plot. From the excerpt, there is an evidence of electism which the author delivers in the novel in the forms of social society situation in the age and the era.

\section{Parody}

Parody is an expression of satisfaction, dissatisfaction, and uncomfortable which deal with parody style identity formed by dramatization of the developed even built up from human feelings (Hatija, 2013). Here is the dialog example.

“ Astaga! Jika demikian, masalah ini pelik. Semoga ini menjadi pelajaran berharga buatmu. Lihat akibatnya kita terdampar disini. Kalian semakin besar, harus menunjukan sikap dewasa yang bertanggung jawab dan penuh perhitungan. Bukan remaja atau kanakkanak--Tidak terima diceramahi kapsul perak itu, Ali mematikan kembali mode suara ILY. "Dasar cerewet!" Ali bersungut-sungut (Liye, 2018: 96). 
In the excerpt, ILY is a technology expresses disappointment and dissatisfaction upon the other characters, Ali and Seli. The excerpt describes dramatization attitude while being stranded in a place and blaming immature attitudes. Such feeling appears when the characters are dissatisfied upon what has been occurring as written in the text. Such indifferent attitude is proven by Ali. It causes the problem which occurs in the dialog. One of the parody evidences in the text is feeling dramatization in such condition so it leads to dissatisfaction of a character toward Ali and Seli's attitudes in the novel. Besides that, here is another example of the parody:

“ Memang dibutuhkan latihan panjang agar kamu tumbuh menjadi petarung dunia paralel yang hebat. Tapi orang tuamu pasti akan bangga sekali melihat dirimu sekarang. Ayahmu, siapapun dia, entah apakah dia masih hidup atau telah meninggal, dia akan bangga." Suara Batazor terdengar serak dan berat. Aku menyeka pipiku yang basah. Aku tidak bisa mencegah diriku menangis (Liye, 2018: 316).

From the excerpt, feeling satisfied and being proud could be seen from Batazor character. He is expressing his pride to the Moon Princess. Becoming a fighter is not easy to achieve. Moreover, that individual must undergo lengthy training. Because of the training, the Moon Princess could be a great fighter. In the description, it could be concluded that "akan bangga sekali", this feeling represents dramatization by Batazor in expressing his pride to the Moon Princess upon what she has reached whether it is noticed by her father or not.

\section{Pastiche}

Pastiche is a dream or imagination. It is a pure imitation without any presentations. Pastiche text is any previous texts to up bring and appreciate (Hatija, 2013). It could be seen in the excerpt:

"Raib bisa bicara dengan alam. Begitulah, aku jadi terinspirasi. Jadi ku namakan sensor paling kuat ILY dengan nama tersebut. Bedanya sensor ILY lebih masuk akal bukan sihir, menggunakan gabungan teknologi tiga klan sekaligus, lebih canggih dibanding sensor milik pasukan bintang. Aku juga tidak perlu menempelkan kuping ke tanah, beratnya. "halo, ada siapa didalam sana? Super raib ada kekuatan baru ILY" (Liye, 2018: 25).

In the excerpt, a character named Ali creates a new censorship. This created censorship is just like a magic but actually it is not. A magic is an inherited and believed culture before modern era. Thus, in the excerpt becomes post-modern aspect evidence in this current era. It is still correlated with term in society and believes to mythical things. In the dialog, ILY is a technological combination among three clans at once. And, the excerpt "tidak perlu menempelkan kuping ketanah", in the dialog, proves that tools to facilitate human are getting faster and meet the requirements. One of them is the ILY. By the invention of ILY, the character in the excerpt does not only put his ears on the ground to search his enemies or other incoming things but also to arrange directly by using ILY technology. 
"ini sangat mengejutkan. Persis dibawah situs kuno yang terkenal itu. Berjarak lima puluh kilometer diperut bumi, ada bangunan kuno besar dalam ruangan kubus raksasa. Modelnya terlihat jelas dilayar. Lebih megah, lebih menakjubkan. Simetris delapan sisi. Bangunan-bangunan setengah boleh terlihat menakjubkan“ (Liye, 2018: 25).

In the excerpt, Ali shows a big screen with fifty kilometer of distance from the center of earth. In the excerpt, it describes an ancient building, "bangunan kuno". It means that the building is a historical heritage or ancient archeology. The imitation which is considered as a symmetric building is much more luxurious. The building does not have any correlation to this ancient building, located in the depth - center of earth in which imaginary will be seen and is as a proof of Ceros' existence in that building. The imitation of the description above proves that pastiche exists in the novel. It describes the ancient building which is still the main idea or masterpiece appearing in post-modern era although the modern era is almost not shown anymore. In the ancient building history, it has very lengthy period, about a century. With this dialog, it describes history and modernity archeology as the time goes on and time changes dynamically.

\section{Irony}

An irony is a challenging matter with expectation and it has become a destiny (Alfadlilah, 2017). Here is the contrary occurrence with certain hope.

"Karena Ceros adalah mereka, Seli. Ngglanggeran dan Ngglanggeram. Si kembar yang berubah wujud menjadi monster badak bercula empat setiap kali malam tiba. Mereka tidak biisa mengendalikan perubahan tersebut tanpa alat yang dicuri". Astaga! Aku dan Seli terdiam. Apakah Ali serius? Atau dia sembarang membuat kesimpulan? (Liye, 2018: 75).

In the excerpt, Ceros is Nggalanggeran and Nggalanggeram. They are the displices as well as Ali and Seli's friends. Seli thinks and does not expect that those two friends transform into four - horned rhinos. Seli who does not completely believe about it while Ali who strengthens about the evidence which reveal the transformation of their friends into Ceros, the four - horned rhinos, in a night.The transformation makes them cannot control their angers and destroys anything around them. This transformation experienced by Ceros becomes a destiny of them. Ali and Seli are surprised by their transformation. Seli is shaken and looks pale because of the transformation of Nggalanggeran and Nggalanggeram. That is the proof of Irony. It proves that such event should not be happened but it eventually happens. Of course, it is in contrast with an expectation which has become a destiny.

\section{Camp}

Camp is a deception which becomes an estetism feature. Camp is also a part of traditions, such as contemporary architecture which acculturates an old element (Faisal, 2013). Besides that, camp is created as the answer of vanity which separates art and social meaning (Pilliang, 2003). Berikutmerupakan data pada novel tersebut: 
"wajah orang yang mengantri itu sama persis dengan foto Batazor sang penjagal yang ada di tablet Miss Selena. Ada bekas luka di wajah, mata kirinya rusak berwarna merah darah, tubuhnya tinggi besar. Dia tidak lagi mengenakan jubah hitam khas klan bulan. Dia sudah berganti pakaian. Jaket kulit, celana berwarna gelap, dan sepatu boot. Terlihat seperti penduduk lain. Rambut panjangnya yang terurai diikat rapi dan ditutupi topi “ (Liye, 2018: 164).

In the excerpt, it describes a similar face Baltazor character. However, in the except, Batazor deceives the enemy's attack. By the evidence, Batazor changes his clothes with leather jacket, dark trousers, and boots which become the evidences of camp aspects in the dialog. The function of the deception done by Batazor is - to not be known by anyone whom do activities, especially in having relationship or having social contact with earthling society. This deception is an evidence of camp in the novel.

\section{CONCLUSION}

Based on the explanation, it could be concluded that there are several postmodernism aspects in Tere Liye's novel of Ceros and Batazor edition that creates electism which combines foreign and domestic cultures. Parody is a discussion about several characters' feelings in the novel. Besides that, there is pastiche which is a dream or expectation of a character in the novel. There is also irony which explains about an expectation of a character. However, it has become a destiny. Finally, postmodernism aspect, the camp has deceptive elements of objects or character in Tere Liye's novel. The development of technology and science could change social life because it could change the advance of the era and new thoughts of the society.

\section{REFERENCES}

Aminuddin. (1991). Pengantar Memahami Unsur Unsur Dalam Karya Sastra.Malng: IKIP.Malang

Alfadlilah, M dan Muhammad Y.E. (2017). Kajian Postmodernisme Pada Novel 'Sirkus Pohon" Karya Andrea Hirata. SENABASABUDI I.hlm: 139-146. Universitas Trunojoyo Madura.

Faisal, Radfan. (2013). Postmodern Pada Novel Maryamah Karpov Karya Andrea Hirata. Jurnal Artikulasi: Jawa Pos Radar Bromo. Vol. 7 No.1: 86-95.

Hatija (2013). Representasi Postmodern Dalam Novel Supernova Edisi Petir Karya Dee Lestari: Tinjauan Sosiologi Postmodern Jean Francois Lyotard. Thesis (S1). Makassar: Universitas Negeri Makassar.

Liye, Tere.(2018). Ceros dan Batazor. Jakarta. PT.Gramedia Pustaka Utama. 
Lyotard, J.F.(1982). The Postmodern Condiition: A Report of Knowladge. Manchester: University Of Menchester.hlm.xi.

Piliang, Yasraf Amir (2003). Hipersemiotika Tafsir Kultural Studies Atas "Matinya Makna". Bandung: Jalasutra.

Rachmawati, Indriyana dan Hasna Wijayanti. (2017). Postmodernisme Perspektif, Kritik, dan Aplikasinya. Yogyakarta. Sociality. 